\title{
Tourist preference on the attraction of beach tourism objects in Kebumen Regency, Central Java Province
}

\author{
Siti Astariningsih Setyoputri ${ }^{1}$, M.H. Dewi Susilowati $1^{*}$, and Ratri Candra Restuti ${ }^{1}$ \\ ${ }^{1}$ Department Geography, Faculty of Mathematics and Natural Sciences, Universitas Indonesia, Depok \\ 16424, Indonesia
}

\begin{abstract}
Tourism is a growing industry sector rapidly. In Kebumen Regency, tourists mostly visit beach tourism objects. This study aims to determine the attractiveness (site attractions, event attractions, supporting facilities, and accessibility) and tourists' preferences to the attractiveness of beach tourism sites in Kebumen Regency. This research was carried out by surveys, data tracing, and data collection from related agencies. The data collected on this research would be processed into maps, tables, and graphics. For analysis, spatial analysis and crosstab statistical tests were used. Tourist objects having high attractiveness are not necessarily the first choice for tourists.
\end{abstract}

\section{Introduction}

One of the industrial sectors that has rapid development is tourism [1]. Tourism from a geographical point of view needs to understand tourists' area of origin, tourist destinations, and the relationsship between tourist areas and tourist destinations, including transportation routes [2]. Tourists will visit tourism sites if there is an attraction [3]. In general, an attraction is based on accessibility, facilities, and the attraction's unique value. Accessibility cannot be separated from the transportation system [4]. The transportation system is related to the local economy, such as accommodation availability and the number of tourists increasing with increasing accessibility [5]. The facilities cannot be separated from the attractions provided by the tourism manager [6].

Beaches are tourism destinations with natural beauty, warm-climate, landscape, culture, and tradition management [7]. Natural, social, and economic resources are represented by beach tourism [8]. The significant component of beach tourism is its natural environment. They are beach sand, the waves, security, and the sights visible [9].

One of the determinant factors of tourists choosing destination tourism is preference [10]. Individual who is traveling has some motives and preferences [11]. To determine the best value of a decided destination, tourists have preferences [12]. The tourist preference is necessary to develop destination tourism [13]. For rural areas that try to combine tourism for their economic development, tourists' opinion is critical $[14,15,16]$. Preferences are

\footnotetext{
* Corresponding author: mhdsusilowati@gmail.com
} 
determined by amenities and accessibilities to destination tourism [17]. Nicholson (2010) states that there are three basic assumptions on preferences: people will not be confused when having two choices [18].

Kebumen Regency is located in Central Java Province, Indonesia. Located in south Java Island and bordering with the Indian Ocean, Kebumen Regency has coastal beaches for tourism. The government of Kebumen Regency is developing and promoting tourism. Tourists preferred to beach tourism sites to others, such as caves [19]. This is in line with the number of tourists who visited the beach in 2015-2019 are 5.470.386. Meanwhile, those who visited the cave in 2015-2019 are 1.848.107.

Preference can participate in the itinerary. In previous research, facilities in Gunung Merapi sites and tourists' characteristics are the variables. These variables use statistical crosstab to identify tourists' preferences of facilities in Gunung Merapi. [20]. Other previous research identified tourist attractions' potential, spatial distribution, and the zonation of tourism in Kebumen Regency. Beach is one of the tourism objects having a high potential for tourist attractions [21]. In this research, tourist attraction and tourism objects were chosen by the tourists are the variables. This research is a quantitative study. To identify tourists' preferences, recent research utilizes statistical crosstab. This research aims to identify tourist attractions of beach tourism sites based on tourists' preferences.

\section{Method}

This research has two data types. They are tourist-attractions variable and tourists preference variable. The tourist-attractions variable is site attractions, event attractions, supporting facilities (accommodations, places to eat, shopping, parking area, worship place, and toilet), and accessibility. This research has two data; they are primary and secondary data. The primary data is destination tourism's absolute location, site attractions, and tourists' preference data. Collecting destination tourism data's absolute location was conducted by marking the locations and digitizing them using the avenza application. For site attraction data, it was collected by observation and searching on the internet. Searching data on the internet was conducted as some location has minimal accessibility. The tourist preference data were collected from questionnaires. This research used quota sampling and accidental sampling, which consisted of 30 respondents and 4 beaches for tourists' preferences. This research was conducted in February 2020.

The secondary data is event attraction, the number of available facilities, administration, road network, and tourists who visited the destinations from 2015 until 2019. The event attractions data and the number of available facilities data were collected from Tourism Government Office Kebumen Regency and data search on the internet. The administration data and the road network data were collected from the Local Development Planning Agency Kebumen Regency. The number of tourists was collected from Tourism Government Office Kebumen Regency.

To process the primary data is used matrix and mapping methods. The matrix method is for tourist preference data. It was classified into two types. They are type A and type B. Type A is the first choice of tourism objects selected by respondents, and type B is not the first choice. The distribution of location tourist attractions map is from plotting and digitalization. The tourist interest toward attractions map is from crosstab's result and for the places of origin map are from the questionnaire. The secondary data was shown in a table. It is for event attractions data and supporting facilities data. The data on the number of tourists is shown in the graphic.

This research used spatial analysis and crosstabs statistical tests. Spatial analysis was used to identify attractions by comparing and equation of tourist attractions objects in Kebumen Regency. After that, the matrix containing site attractions, facilities, and accessibility was 
created. Crosstabs statistical test was used to find out the preferences of tourists toward attractions.

\section{Results and discussion}

\subsection{Tourist attractions}

Nature beauty in coastal can be explored and be enjoyed by tourists [22]. Tourism objects in the beach tourism Kebumen Regency are various characteristics. Tourist attractions in Kebumen Regency have their main site attraction in waves, consisting of big waves and small waves. There is also a primary site attraction in the mangrove forest. In addition to that, there is also a lagoon as the primary site attraction in tourism sites.

Table 1. Site attractions inbBeach tourism sites Kebumen Regency.

\begin{tabular}{cc}
\hline Tourism Objects & Site Attraction \\
\hline Logending Beach & Small wave, mangrove forest \\
Wediputih Beach & Small wave, rock, waterfall \\
Sawangan Beach & Small wave, rock, cave, waterfall, 'I Love U' Bridge \\
Menganti Beach & Small wave, white sand, Sigatel Hill, Sigatel Cliff, Menguneng Valley, \\
& lighthouse, red bridge, \\
Surumanis Beach & Small bridge, rock, Saga Hill, half-round bridge \\
Pantai Lampon & White sand, cave, "Love” Bridge, small wave \\
Watubale Beach & Small wave, triangle bridge, treehouse, miniature 'Eiffel' \\
Karangbolong Beach & Artificial cave, Hud Hill, big wave \\
Suwuk Beach & Big wave \\
Bopong Beach & Lagoon, big wave \\
Petanahan Beach & Big wave \\
Setrojenar Beach & Sand dune, big wave \\
Ambal Beach & Sand dune, big wave \\
Lembupurwo Beach & Sand dune, lagoon, big wave, pinery park \\
\hline
\end{tabular}

Besides those site attractions mentioned above, beach tourism in Kebumen Regency has regular event attractions. These event attractions are held annually, daily, and incidentally. One of the most popular attraction events among the tourists is the New Year's event. Every day, tourists can also see the attractive event in the fish market or TPI (Fish Auction Place). There is also an unexpected attraction event that cannot be missed; it is Rekade (Retro Karepe Dewe).

Table 2. Event attractions in beach tourism sites Kebumen Regency.

\begin{tabular}{cc}
\hline Tourism Objects & Event attraction \\
\hline Logending Beach & Boat, fish auction \\
Wediputih Beach & - \\
Sawangan Beach & - \\
Menganti Beach & Kisik Harmony New Year Eve, surfing, fish auction, shuttle car \\
Surumanis Beach & - \\
Lampon Beach & - \\
Watubale Beach & New Year Eve with tour manager \\
Karangbolong Beach & A ritual before taking swift's nest \\
Suwuk Beach & Horse riding, boat, swimming pool \\
Bopong Beach & Horse riding, rowing boat \\
Petanahan Beach & Love and Flower and Kebumen Day's Ceremony, Kite Exhibition, yellow \\
& pandanus ritual, horse riding, Rekade, children's ride
\end{tabular}




\begin{tabular}{cc}
\hline Tourism Objects & Event attraction \\
\hline Setrojenar Beach & Rekade, horse riding, children's ride \\
Ambal Beach & Horde riding, swimming pool \\
Lembupurwo Beach & Horse riding, rowing boat, swimming pool, Grebek Rowo ritual, \\
& Sandboarding \\
\hline
\end{tabular}

Supporting facilities are needed to fulfill tourists' needs and want [23]. Supporting facilities can be found on shoreline [24]. The supporting facilities in beach tourism objects in Kebumen are secondary facilities and conditionally facilities. The secondary ones are accommodations, food and beverages, and shopping area. And the conditional ones are mushollas or mosques, toilets, and parking.

Accommodations in beach tourism Kebumen Regency, only Menganti Beach and Watubale Beach have accommodations, where the highest number is Menganti Beach. There are villas in Menganti Beach, and there are hostels in Watubale. Suwuk Beach has the highest number of food and beverages and shopping area. On the itinerary, food and beverage service is preferred by tourists [25]. Food and beverages in beach tourism Kebumen Regency are food stalls. The previous study state that tourists to coastal areas for holidays tend to demand local seafood be present on the menu [26]. Food stalls in beach tourism Kebumen Regency sell seafood like yutuk (sand crabs). The secondary facilities in Beach Tourism Sites Kebumen Regency based on Tourism Government Office Kebumen Regency, observation, and data source, see Figure 1.

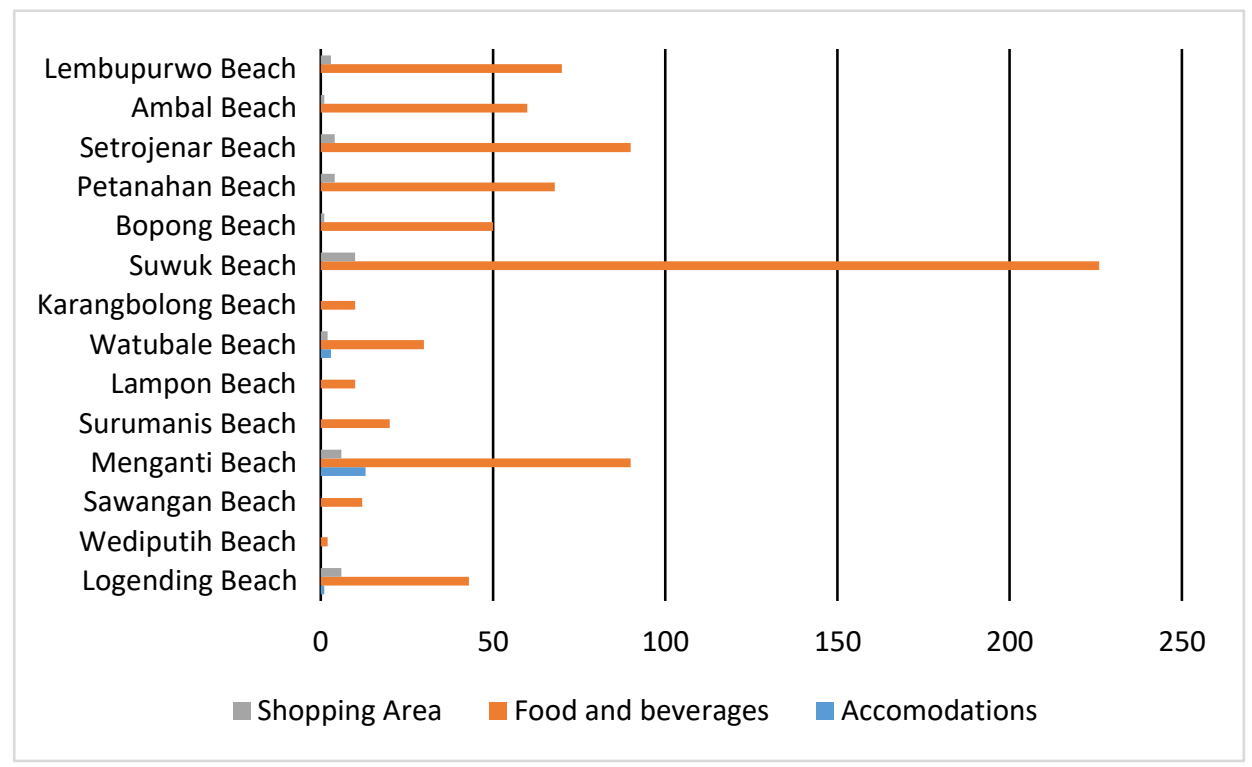

Fig.1. Secondary facilities in beach tourism sites Kebumen Regency.

Suwuk Beach has the most toilets. Only Petanahan Beach, Suwuk Beach, and Menganti have the most mushollas. $\mathrm{T}$ here are three kinds of accommodated vehicles in the parking area: motorcycles, cars, and oversized vehicles (like buses). Logending Beach, Suwuk Beach, and Petanahan Beach can accommodate three kinds of vehicles. The conditional facilities in Beach Tourism Sites Kebumen Regency based on Tourism Government Office Kebumen Regency, observation, and data source, see Figure 2. 


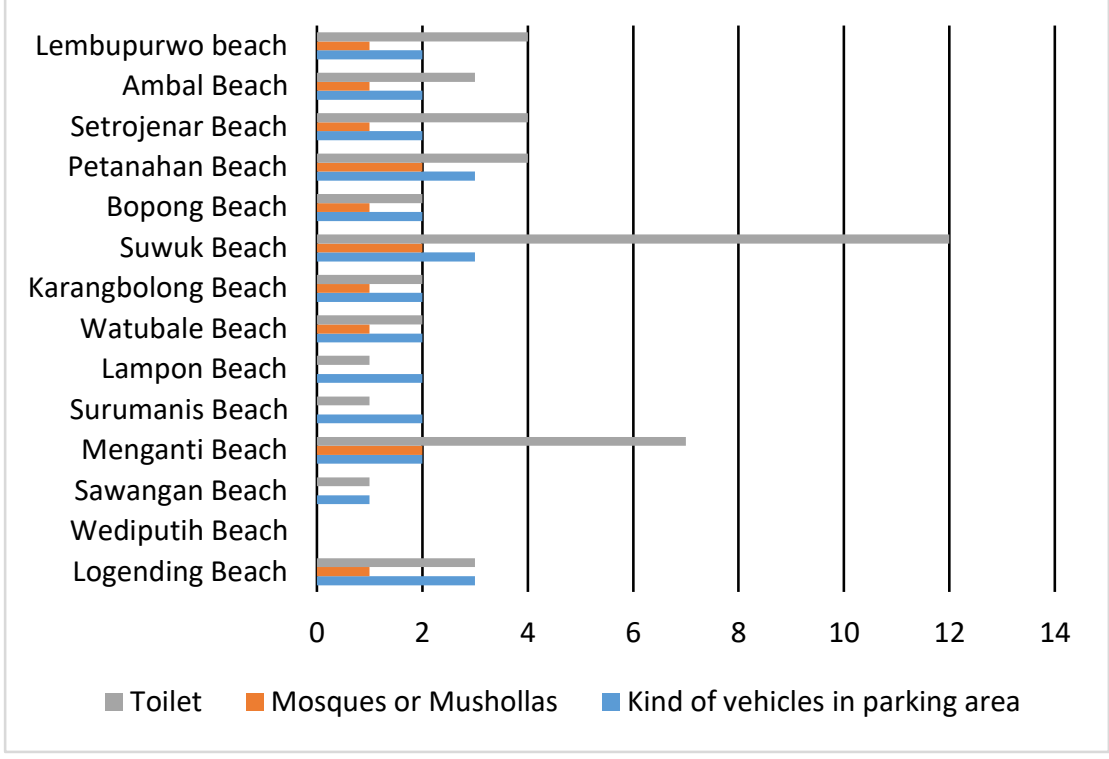

Fig.2. Conditionally Facilities in Beach Tourism Site Kebumen Regency.

The majority of tourism sites in Kebumen Regency are in the local road class. Only Suwuk Beach is located in arterial road class. The modes of transportation passed by three types of vehicles are Logending Beach, Suwuk Beach, and Petanahan Beach. Suwuk Beach can be passed by the bus because it is in arterial road class. While Logending Beach and Petanahan Beach can be passed by buses even though they are in the local road class, the roads are gentle, not winding, and have sharp turns.

Table 3. Road Class to Tourism Objects.

\begin{tabular}{cc}
\hline Road Class & Tourism Objects \\
\hline Artery & Suwuk Beach \\
Collector & Petanahan Beach \\
Local Road, accessible & Logending Beach \\
by big vehicles & Sawangan Beach, Menganti Beach, Surumanis Beach, Lampon Beach, \\
& Watubale Beach, Karangbolong Beach, Bopong Beach, Setrojenar \\
Local Road & Beach, Ambal Beach, Lembupurwo Beach \\
& Wediputih Beach \\
Another Road &
\end{tabular}

Measurement of level-tourist attraction, see table 4.

Table 4. Measurement of level tourist-attraction.

\begin{tabular}{|c|c|c|c|}
\hline \multirow{2}{*}{$\begin{array}{l}\text { Attributes of Tourist } \\
\text { Attractions }\end{array}$} & \multicolumn{3}{|c|}{ Level tourist-attraction } \\
\hline & Low & Moderate & High \\
\hline Site Attraction & $<4$ & $4-5$ & $>5$ \\
\hline Event Attraction & $<2$ & $2-3$ & $>3$ \\
\hline Secondary Facilities & $<80$ & $80-158$ & $>158$ \\
\hline Conditionally Facilities & $<6$ & $6-10$ & $>10$ \\
\hline Accessibility & $\begin{array}{c}\text { Another road, no } \\
\text { accessible by any vehicles }\end{array}$ & $\begin{array}{l}\text { Collector or local } \\
\text { road, no accessible } \\
\text { by big vehicles }\end{array}$ & $\begin{array}{l}\text { Artery or collector } \\
\text { road, accessible by } \\
\text { big vehicles }\end{array}$ \\
\hline
\end{tabular}


If the beach tourism sites have $\geq 3$ attributes of tourist attractions on a high-level, it will be categorized as tourism sites with high attractiveness. If the beach tourism site has $<3$ attributes of tourist attractions on moderate and high-level, it will be categorized as tourism sites with low attractiveness. And If the beach tourism site has $\geq 3$ attributes of tourist attractions on a moderate-level, it will be categorized as tourism sites with average attractiveness.

Tourism sites with high attractiveness are Menganti Beach and Suwuk Beach. This is classified into two, namely attractions and other facilities, attractions, accessibility, and other facilities. The tourism site that is included in the classification of attractions and other facilities is Menganti Beach. These attractions are in the form of site attraction and event attraction. Other facilities include accommodation. Meanwhile, a tourism site included in the classification of attractions, accessibility, and other facilities is Suwuk Beach. These attractions are in the form of site attraction and event attraction. Other facilities include a parking space that can accommodate three types of vehicles: motorbikes, cars, and buses.

Tourism sites with moderate attractiveness are classified into attractions, other facilities, and other attractions and facilities. A tourist attraction that is classified as an attraction is Lembupurwo Beach. These attractions are in the form of site attraction and event attraction. A tourist attraction included in other facility classifications is Setrojenar Beach, which has the most significant number of places to eat among other tourism sites with moderate attractions. Meanwhile, a tourism site that is classified as attractions and other facilities is Petanahan Beach. The attraction is in the form of event attraction. Other facilities include a parking space that can accommodate three types of vehicles.

Tourism sites with low attractiveness are classified into two, namely attractions; and other attractions, accessibility, and facilities. The tourism sites classified as attractions are divided into two, namely attractions in the form of site attraction and attractions in the form of site attraction and event attraction. Tourist sites classified as site attractions are Wediputih Beach, Sawangan Beach, Surumanis Beach, Lampon Beach, Watubale Beach, Bopong Beach, and Ambal Beach. The tourism site, which is classified as an attraction site and event attraction, is Karangbolong Beach. Meanwhile, a tourist site classified as attractions, accessibility, and other facilities is Logending Beach. These attractions are in the form of site attraction and event attraction. It has the accessibility to be passed by buses. Other facilities include a parking space that can accommodate three types of vehicles. Tourist attractions with high attractiveness are in the western and central parts, namely Menganti Beach in the west and Suwuk Beach in the middle. Most of the tourist attractions with moderate interest are in the eastern part, but some are located in the middle. Tourist attractions with a moderate appeal on the eastern coast are Setrojenar Beach and Lembupurwo Beach. A tourist attraction with moderate interest, which is located on the central coast, is Petanahan Beach. Meanwhile, most tourism sites with low attractiveness are in the western part, but some are located in the central and eastern parts. Tourist attractions with low attractiveness located in the western part are Logending Beach, Wediputih Beach, Sawangan Beach, Surumanis Beach, Lampon Beach, Watubale Beach, and Karangbolong Beach. Meanwhile, a tourist attraction with low attractiveness located on the eastern coast is Ambal Beach.

\subsection{Number of tourist}

In 2015-2019, Menganti Beach and Suwuk Beach were more excellent than others. Menganti Beach has a stable number of tourists, but Suwuk Beach tends to decline. This is due to the large waves in the southern ocean, which was affected by Suwuk beach. Logending Beach and Petanahan beach have fluctuation. Wediputih Beach, Sawangan Beach, Surumanis Beach, Watubale Beach, Bopong Beach, Setrojenar Beach, Ambal Beach, and Lembupurwo Beach are new, so data is incomplete. For the number of tourists, see Figure 3. 


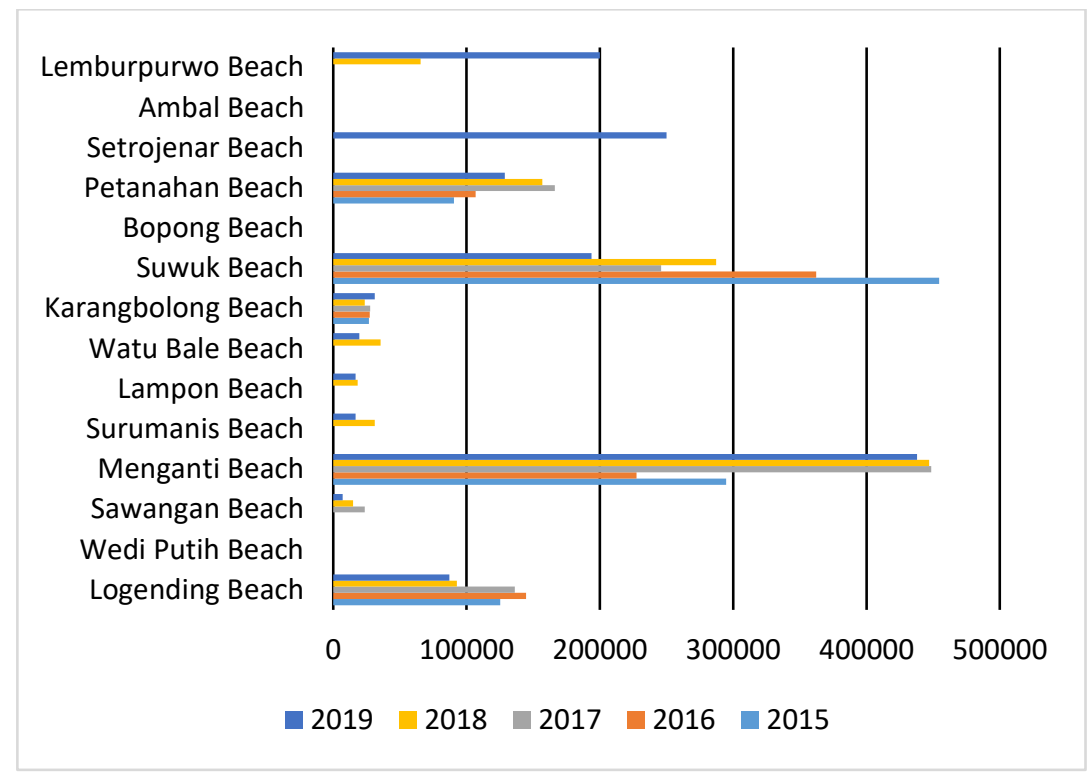

Fig.3. Number of Tourists of Beach Tourism Objects in Kebumen Regency.

\subsection{Tourists' preference}

One of determining tourist behavior is preference [27]. Based on table 5, the first choice with the highest number is Menganti Beach. "Menganti Beach has its beautiful nature, white sand, and small wave that we can enjoy." The respondents like to visit Menganti Beach because of the site attraction that Menganti Beach has. At the same time, the not first choice with the highest number is Suwuk Beach. "Suwuk Beach is near Karangbolong", "Suwuk Beach is near my house", "Suwuk Beach is crowded with visitors", "Suwuk Beach is accessible and has complete facilities", "Suwuk Beach has some photo spots". The respondents like to visit Suwuk Beach because near another tourism site, the respondent's origin, crowded with visitors, accessible, and complete facilities.

Table 5. Tourists' Preferences of Beach Tourism Sites.

\begin{tabular}{ccc}
\hline Tourism Objects & First Choice & Not First Choice \\
\hline Logending Beach & 1 & 2 \\
Wediputih Beach & 0 & 1 \\
Sawangan Beach & 0 & 1 \\
Menganti Beach & 13 & 6 \\
Surumanis Beach & 0 & 1 \\
Lampon Beach & 0 & 1 \\
Watubale Beach & 0 & 3 \\
Karangbolong Beach & 0 & 5 \\
Suwuk Beach & 6 & 13 \\
Bopong Beach & 0 & 4 \\
Petanahan Beach & 2 & 10 \\
Setrojenar Beach & 4 & 4 \\
Ambal Beach & 1 & 3 \\
Lembupurwo Beach & 3 & 3 \\
\hline
\end{tabular}


Respondents who were interviewed by the questionnaire came from Kebumen Regency and from outside of Kebumen Regency. The majority of respondents came from Kebumen Regency. The respondents came from Ambal, Karanganyar, Sruweng, Kuwarasan, Pejagoan, Sempor, Adimulyo, Karanggayam, Alian, and Bonorowo Districts. Besides, some respondents came from outside Kebumen Regency. Banjarnegara Regency, Purworejo Regency, Bandung Regency, Bekasi Regency, Banyumas Regency, and Jakarta are the origin of respondents from outside of Kebumen Regency.

For the result of crosstabs, see Table 6.

Table 6. Crosstabs Level of Tourist Attraction with Preference

\begin{tabular}{|c|c|c|c|}
\hline \multirow{2}{*}{ Preference } & \multicolumn{3}{|c|}{ Level of Tourist Attraction } \\
\cline { 2 - 4 } & High & Moderate & Low \\
\hline First & $\begin{array}{c}\text { Menganti } \\
\text { Beach }\end{array}$ & $\begin{array}{c}\text { Setrojenar Beach, } \\
\text { Lembupurwo Beach }\end{array}$ & - \\
\hline $\begin{array}{c}\text { Not First } \\
\text { Choice }\end{array}$ & $\begin{array}{c}\text { Suwuk } \\
\text { Beach }\end{array}$ & Petanahan Beach & $\begin{array}{c}\text { Logending Beach, Wediputih Beach, Sawangan } \\
\text { Beach, Surumanis Beach, Lampon Beach, } \\
\text { Watubale Beach, Karangbolong Beach, Bopong } \\
\text { Beach, Ambal Beach }\end{array}$ \\
\hline
\end{tabular}

A tourist attraction included in the type A preference category or the first choice with high attractiveness is Menganti Beach. Menganti Beach was chosen as the first choice because of the site attraction offered. The tourism sites that are the preferred first choice with moderate attractiveness are Setrojenar Beach and Lembupurwo Beach. Setrojenar Beach is the first choice because the ticket prices are affordable and close to home. Meanwhile, Lembupurwo Beach was chosen as the first choice because of the site attraction it offers. Coastal provides uniqueness and charming places for tourists [28].

A tourist attraction that is not the first choice with high attractiveness is Suwuk Beach. Suwuk Beach is not the first choice not because of the attractiveness it offers, but because it is crowded with visitors, near another tourism site, the origin of respondent, accessible, and complete facilities. This is in line with tourism sites in the last 5 years, having the largest tourist attractions after Menganti Beach. There is a tourist on categorized psychocentric [6]. It is tourists who like to visit places that they are familiar with. The respondents chose Suwuk Beach because near their house, probably because they prefer to visit places they are familiar with. A tourist attraction that is not the first choice with the moderate appeal is Petanahan Beach. Petanahan Beach was chosen because of the site attraction, close to the house, and in the direction of other tourism sites, namely Suwuk Beach. Tourist attractions that are not the first choice with low attractiveness are Logending Beach, Wediputih Beach, Sawangan Beach, Surumanis Beach, Lampon Beach, Watubale Beach, Karangbolong Beach, Bopong Beach, and Ambal Beach. Logending Beach was chosen because of the event attraction, while Wediputih Beach and Sawangan Beach were chosen because it is considered still natural. Surumanis Beach was chosen because the ticket price was affordable, but it was far from where the respondents were. Lampon Beach was chosen because of the sea view. Watubale Beach was chosen because of its beautiful nature and many places to take pictures. There is a lagoon, and it is close to the house, which is why tourists choose the preferred Bopong Beach. The respondent chose Ambal Beach because it is close to home and relatives. The map of Tourists' Preference on the Attraction of Beach Tourism Objects in Kebumen Regency was processed by author, see Figure 4. 


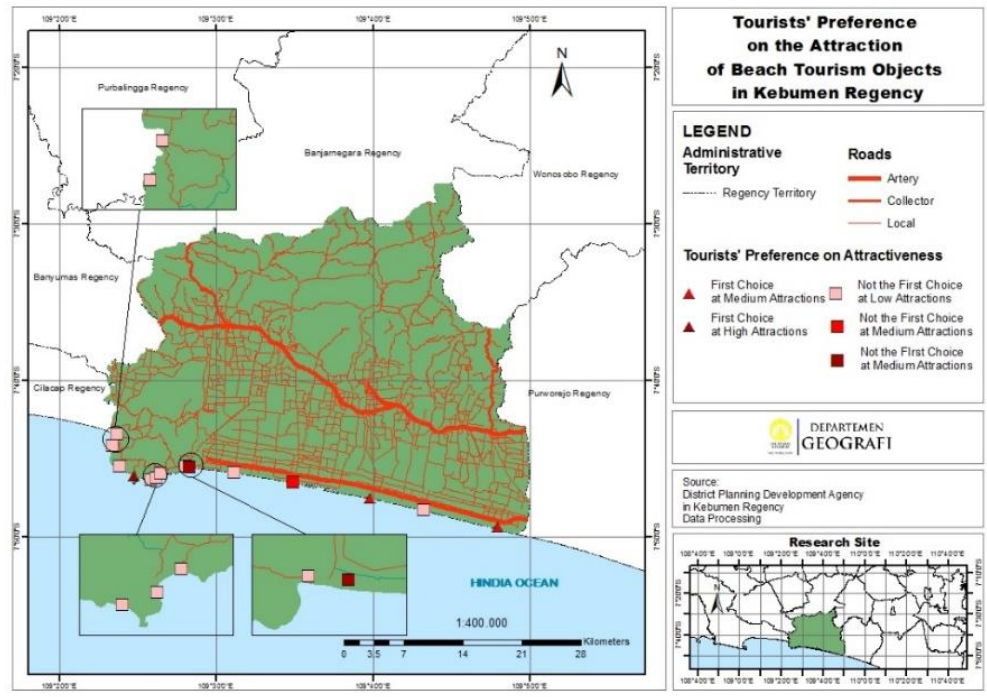

Fig. 4. Tourist Preference on the Attraction of Beach Tourism Sites in Kebumen Regency, Central Java Province

\section{Conclusion}

The majority of the beach- tourism sites in Kebumen Regency have low-level tourist attractiveness. That is from the measurement of level-tourist attraction. Only two beachtourism sites have high-level tourist attractiveness. Based on tourist preferences' crosstab results with tourist attractions, tourism sites with high attractiveness have different preferences. In this case, Menganti Beach is a tourist attraction with high attractiveness, and it is the first choice among tourists. Meanwhile, Suwuk Beach is a tourist attraction with high attractiveness, but it is not the first choice. This is because tourist preferences are not determined by the attractions offered by the tourism sites.

\section{Acknowledgement}

This study is supported and funded by University of Indonesia under the Publikasi Terindeks Internasional (Hibah PUTI) research grant 2020.

\section{References}

1. Anonymous, Sustainable Tourism Development in UNESCO Designated Sites in South-Eastern Europe, Venice: UNESCO http://portal.unesco.org/en/files/45338/12417872579Introduction_Sustainable_Touris m.pdf/Introduction_Sustainable Tourism.pdf

2. A. Lew, C.M. Haal, D. Timothy, World Geography of Travel and Tourism A Regional Approach, Canada: Elsevier Inc (2008)

3. G. Suwantoro, Basics of Tourism, Yogyakarta: Andi Yogyakarta (2004)

4. G. Moscardo, Visitor Evaluations of Built Tourist Facilities: Pontoons on the Great Barrier Reef, Journal of Tourism Studies, 12, 28-38 (2001)

5. R. Burton, Travel Geography, London: Pitman Publishing (1995) 
6. R.K Judisseno, Aktivitas dan Kompleksitas Kepariwisataan, Jakarta: PT Gramedia Pustaka Utama, 196 (2017)

7. M. Prabpriree, T. Maneenetr, P. Siriwong, K. Yaipool Implementing Sustainable Beach Tourism Management Framework for the Royal Coast Cluster, Asian Social Science, 12, 147 (2016) http://dx.doi.org/10.5539/ass.v12n8p146

8. Z. Zadel, Beaches in the Function of Primary Resource of the Beach Tourism Product, Pomorski zbornik, 51, 118 (2016)

9. B. Kirubashini and Ameen C. P., Beach Tourism: Domestic Tourists' Experience with Special Reference to Beaches in North Kerala, International Journal of Management Studies, VI, 125 (2019) http://dx.doi.org/10.18843/ijms/v6i1(5)/14

10. P. E. Murphy. Tourism, A Community Approach, New York-London: Methuen. (1985)

11. Dineshkumar, Siranjeevi. M.S, Benita S Monica, Study on Tourism Preferences in Chennai, International Journal of Engineering Development and Research 6, 565 (2018)

12. F. N. Azizah, D.R.K. Kausar, I M.A. Gunadi, Y. Yuan, Preferences of Indonesian Outbound Tourists Toward Travel Types and Tourism Attributes, Proceedings of The First International Conference on Global Innovation and Trends in Economy, InCoGITE, (2019) https://doi.org/10.4108/eai.7-11-2019.2295244

13. S.P. Siagian, Teori Motivasi dan Aplikasinya, Jakarta: Bina Aksara (1989)

14. D.K. English, D.W. Marcouiller, and H.K. Cordell, Tourism Dependence in Rural America, Society and Natual Resources, 13, 185-22 (2000)

15. A. Murray and C. Kline, Rural Tourism and the Craft Beer Experience: Factors Influencing Brand Loyalty in Rural North Carolina, USA, Journal of Sustainable Tourism 23 (8-9), 1198-1216 (2015) http://dx.doi.org/10.1080/09669582.2014.987146

16. B.P. Mimbs, B.B. Boley, J.M. Bowker, K.M. Woosnam, G.T. Green, ImportancePerformance Analysis of Residents' and Tourists' Preferences for Waterbased Recreation in Southeastern United Statess Journal of Outdoor Recreation and Tourism 31, 2 (2020) https://doi.org/10.1016/j.jort.2020.100324

17. Nandi, Pariwisata dan Pengembangan Sumberdaya Manusia (2008)

18. W.Nicholson and C. Snyder, Intermediate Microeconomics and Its Applications (Canada: Cangage Learning bt Nelson Education, LTD), 55-56 (2010)

19. W.A. Prodjo, Hitung Jumlah Wisatawan, Tiket Masuk Obyek Wisata Dibedakan, Kebumen: Kompas (2017)

https://travel.kompas.com/read/2017/10/25/093500827/hitung-jumlah-wisatawantiket-masuk-obyek-wisata-kebumen-dibedakan

20. Roby Dwiputra, Preferensi Wisatawan Terhadap Sarana Wisata di Kawasan Wisata Alam Erupsi Merapi (Tourist Preference for Tourism Facilities in the Eruption of Merapi Nature Tourism Areas) 24, 35-48 (2013)

21. A. Waidah, Zonasi Pariwisata Berdasarkan Potensi Sumber Daya Tarik Wisata di Kabupaten Kebumen Berbantuan Sistem Informasi Geografis (Tourism Based on the Potential of Tourist Attractions in Kebumen District Aided by Geographical Information Systems ), (2017)

22. M.N Nobi and Md.A. Majumder, Coastal and Marine Tourism in the Future, J. Ocean Coastal Econ., 6, 5 (2019) https://doi.org/10.15351/2373-8456.1101

23. Isdarmanto, Dasar-Dasar Kepariwisataan dan Pengelolaan Destinasi Pariwisata, Yogyakarta: Gerbang Media Aksara dan StiPrAm (2017)

24. D. Tegar R. and R.O.S. Gurning, Development of Marine and Coastal Tourism Based in Blue Economy, International Journal of Marine Engineering Innovation and Research, 2, 128-132 (2018) http://dx.doi.org/10.12962/j25481479.v2i2.3650 
25. T.H. Tsai and C.M. Chen, Evaluating Tourists' Preferences for Attributes of the Thematic Itiniraries: Holy Flokore Statue in Kinmen Tourism Management Perspetives 30, 210 (2019) https://doi.org/10.1016/j.tmp.2019.02.010

26. M. Honey and D. Krantz, Global Trends in Coastal Tourism, Washington DC: Marine Program World Wildlife Fund, 19 (2007)

27. S. Amir, M.M. Osman, S. Bachok, and M. Ibrahim, Understanding of Tourists' Preferences Pattern: A Study in Melaka, Malaysia, Journal of the Malaysian Institute of Planners, III, 81-94 (2014) https://doi.org/10.21837/pmjournal.v12.i3.133

28. T. Ghosh, Coastal Tourism: Opportunity and Sustainability, Journal of Sustainable Development, 4, 67 (2011) http://dx.doi.org/10.5539/jsd.v4n6p67 